STUDI

FRANCESI

\section{Studi Francesi}

Rivista quadrimestrale fondata da Franco Simone

188 (LXIII | II) | 2019

Penser/peser le Moyen Âge entre XVe et XVIIe siècle:

parcours de recherche - sous la direction de Maurizio

Busca et Piero Andrea Martina

\title{
Michèle Clément, Une poétique de crise. Poètes baroques et mystiques (1570-1660)
}

\section{Laura Rescia}

\section{OpenEdition \\ Journals}

Edizione digitale

URL: http://journals.openedition.org/studifrancesi/19684

DOI: 10.4000/studifrancesi. 19684

ISSN: 2421-5856

\section{Editore}

Rosenberg \& Sellier

Edizione cartacea

Data di pubblicazione: 1 août 2019

Paginazione: 350

ISSN: 0039-2944

Notizia bibliografica digitale

Laura Rescia, «Michèle Clément, Une poétique de crise. Poètes baroques et mystiques (1570-1660)», Studi Francesi [Online], 188 (LXIII | II) | 2019, online dal 01 février 2020, consultato il 25 janvier 2021. URL: http://journals.openedition.org/studifrancesi/19684; DOI: https://doi.org/10.4000/studifrancesi. 19684

Questo documento è stato generato automaticamente il 25 janvier 2021.

\section{(†) $९$

Studi Francesi è distribuita con Licenza Creative Commons Attribuzione - Non commerciale - Non opere derivate 4.0 Internazionale. 


\title{
Michèle Clément, Une poétique de crise. Poètes baroques et mystiques (1570-1660)
}

\author{
Laura Rescia
}

\section{NOTIZIA}

Michèle Clément, Une poétique de crise. Poètes baroques et mystiques (1570-1660), Paris, Classiques Garnier, 2018, 434 pp.

1 Segnaliamo la ristampa del volume apparso nel 1996 nella collana «Bibliothèque littéraire de la Renaissance». Vent'anni dopo, alcune parti di questo ragguardevole lavoro necessiterebbero di revisione, quali l'intero primo capitolo, dedicato alla discussione della nozione di barocco, il sesto, improntato a nozioni di linguistica che oggi sembrano meno interessanti di allora, oltre, naturalmente, alla bibliografia generale e critica. Tuttavia, la bibliografia primaria, centrata sulle poesie mistiche e gli scritti spirituali di poeti noti e meno noti, mantiene un sicuro interesse, che probabilmente giustifica l'operazione editoriale dei Classiques Garnier. 